\title{
The Utilization of the Environment as A Source of Social Science: Resilience of SMEs Amid the Covid-19 Pandemic
}

\author{
Tetep $^{1, *}$ Triani Widyanti ${ }^{2}$
}

\author{
${ }^{1}$ Institut Pendidikan Indonesia \\ ${ }^{2}$ Institut Pendidikan Indonesia \\ *Corresponding author.Email: tetep@institutpendidikan.ac.id
}

\begin{abstract}
The resilience of Small and Medium Enterprises (SMEs) is a growing socio-economic issue associated with a weakening economy. The research method used was descriptive. It aimed to see the extent to which SMEs in Garut in surviving the Covid-19 pandemic that hit Indonesia. The results of data analysis showed that most of the studied SMEs demonstrated sufficient resilience to weather the shock of the Covid-19 pandemic. It means that SMEs in Garut had a strong entrepreneurial spirit and was able to seek out various innovations to keep their business sustainable. Therefore, the socio-economic phenomenon is considered to be a relevant source of meaningful social science.
\end{abstract}

Keywords: Social Environment, Social Science Resources, Small And Medium Enterprises, Covid-19 Pandemic.

\section{INTRODUCTION}

The Covid-19 (Corona Virus Disease) pandemic has become a new problem for various countries in the world [1], including Indonesia. The increasing case of Covid-19 in Indonesia has forced the government to apply the policy, The Large- Scale of Social Restrictions (PSBB), which aims to break the spreading of the virus. The transmission of the Covid-19 has significant impact in many sectors. Not only does it have impact in the health and public services, but it also has also paralyzed various sectors of human life such as education, economy and tourism. In the field of education, the government has issued a police to learn from home (daring/online learning) which should be done in any level. In other hand, the policy has made a wave of layoffs and the weakening of the micro, small and medium enterprises (MSMEs) in economy. Therefore, there many MSMEs that are also affected by the Covid19 pandemic in Garut. It is particularly evident from the decreasing purchasing power of the community as a result of the increasing number of layoffs.
Most economic experts predict that MSMEs will not be able to avoid this condition. The MSME sector is considered the most vulnerable to the Covid-19 driven economic crisis. It is caused that MSMEs are very dependent on the turnover of money from selling their products. Based on data from the Ministry of Cooperatives and SMEs [2], there are at least 64 million MSMEs in Indonesia. It means that the government still cannot solve major problems related to MSMEs. Therefore, it is required to have good synergy between all communities. However, it is interesting to know that MSMEs in Garut is able to survive in facing the pandemic. Based on the above phenomena, the impact of the Covid-19 outbreak on various sectors can be used as a reference or learning resource, especially for social studies subjects, which include studies on the economy and socio-culture. Based learning enviroment is expected to be able to become a meaningful learning so that knowledge can be implemented in everyday life.

According to WHO, pandemic refers to the disease which spreads in a global scale. It becomes the highest level condition when it can spread rapidly among a greater number of people. Meanwhile, according to the 
United States Public Health Institute, Center for Disease Control and Prevention (CDC), a disease become a pandemic when the virus can easily infect humans and spread from human to others in an efficient and sustainable manner in various regions. Therefore, Covid-19 was declared a pandemic by WHO as a warning to all countries in the world to increase preparedness in preventing and dealing with the spreading of it. In addition, all countries are required to be able to detect, test, treat, isolate, track and monitor the movements of their people. The main purpose of defining the term of pandemic is to raise awareness of the importance of clean life. However, the term has sparked and become global panic which then has an impact on various aspects in humanity [4]. According to the Indonesian pulmonary medical association, Covid19 is a large family of viruses that cause disease in humans. It was only discovered after an extraordinary event that occurred in the Chinese city of Wuhan in December last year, which was called SARS-COV2 and caused the Covid-19 disease [5].

MSMEs are trading businesses managed by business entities or individuals which refer to productive economic enterprises as stipulated by Law of the Republic of Indonesia Number 20 of 2008. UMKM MSMEs according to the Ministry of Cooperatives and SMEs in reference [5] page 8 refer to small businesses that have a net worth of at most Rp. 200,000,000, excluding land and buildings for business premises and has annual sales of not more than Rp. 1,000,000,000. Meanwhile, medium-sized enterprises are businesses owned by Indonesian citizens with a net that is greater than Rp. 200,000,000. According to reference [7], MSMEs becomes productive businesses that can be developed to support macro and micro economic development in Indonesia and influences other sectors to develop. It can be a solution to reduce the poverty in Indonesia. It is supported by reference [8] that the socioeconomic background, family economic education and literacy provide a significant impact for students to make a decision. Poverty alleviation by developing MSMEs has become a quite good potency which greatly contributes in providing a work for employment more than $99.45 \%$ of the workforce and contributing to GDP of around $30 \%$.

According to reference [9] the learning resources play an essential role in solving problems in learning. They can be identified as messages, people, materials, tools, techniques, and settings. In addition, they refer to anything that can provide information in learning. According to reference [10] page 170, In social science, there are many learning resources that enable to be used in supporting the learning process and learning outcomes, both at school and outside the school environment [11]. They are defined as information that is presented and stored in various forms of media that can help students learn, as a manifestation of the curriculum while reference [12] page states that learning resources are anything that can be used by students to learn according to their goals. Teachers must develop and design learning resources systematically based on the learning needs and characteristics of the students [13]. In other hand, Nursid in reference [14] said that the learning process and resources are required by students to achieve their learning goals. Then, it can be said that learning resources can be in the form of the surrounding environments, such as natural environments, social environments, cultural environments, and psychological environments. It is a line with Hutama's opinion in reference [15] that the socio-cultural approach is an approach and organization of material that presents a real copy (portrait) of people's daily life, both in its social and cultural dimensions comprehensively into the classroom, based on contextual situation. Through the representation of real portraits of the socio-cultural dimensions in the classroom, students are expected to learn based on the real world, so they do not get a shocked experience in learning.

\section{METHODS}

The research method used was a descriptive qualitative method. The technique of data collection used was observation, interviews, documentation, and triangulation. The primary data sources came from the participants who were selected using the snowball sampling technique. It aimed to increase the number of participants by asking participants who have been interviewed or other related parties to recommend other potential participants [16]. Meanwhile, secondary data were obtained through supporting data that related to the context of the research obtained by researchers from information about the problems to be studied.

\section{RESULTS AND DISCUSSION}

The number of micro businesses in Garut has reached more than 51 thousand units with total turnover reaching 1.79 trillion in 2017. It was greater than the number of MSMEs in other areas in West Java. The MSMEs in Garut grows more increasingly with the processed food such as dodol, and traditional cakes, also leather products like bags, wallet and jacket. There are several programs from the Garut Regency administration that has helped to increase the MSMEs' income. The Covid-19 pandemic has also affected the MSME which couldn't be avoided. Therefore, this condition forces the MSME to survive. The result of the research showed that MSMEs in Garut had got enormous difficulties during the last few months since the government applied PSBB policy. As the result, there were many layoffs and it caused in the decreasing of the people purchasing. In addition, the pandemic had also caused a decline in the number of tourists who 
visited to Garut so that tourist objects and shopping centers were deserted of visitors. The tourism industry is one of the industries affected by the spread of Covid-19 [17]. Likewise, a well-known a chocolate culinary company in Garut had carried out various innovations to survive the pandemic y by adjusting products which were usually tourism-based into daily consumption. The daily consumption products no longer had the theme of Garut tourism, but still used unique packaging to attract local consumers. In other hand, MSMEs in Garut were also restricted by the difficulty to get the raw materials. The scarcity of some raw materials caused in high production and distribution costs. The high cost was not a line with the number of the sales which were decreasing in a day, even closer to zero sales. A study conducted by the Indonesian Ministry of Finance revealed that the Covid-19 pandemic had negative impacts on the domestic economy, such as decreasing consumption and purchasing power, decreasing company performance, weakened banking and financial sectors [18].

However, based on the results in observations and interviews, MSMEs in Garut tended to survive the Covid-19 pandemic. Even though, the income in MSMEs has decreased, they still continue to their business with various innovations. It can be seen that they used social media as a tool for selling their products in online market. It can help to make up for the lack of direct sales. The various innovations are carried out by looking at business opportunities that might be promising in pandemic such as the producing mask in the fashion sector. Thus, the MSMEs in Garut Regency tended to have good resilience in the economic crisis due to the Covid-19 pandemic.

The fact that the economic crisis and challenges had been able to be overcome by MSMEs in Garut was an interesting thing to be used as a source of social science. There must be a prompt and appropriate solution to recent difficult conditions. Social science based on environmental conditions is expected to be able to provide relevant, effective and efficient information to students so that social science becomes more meaningful. It is expected that these students will not easily give up on any conditions they face in the future. Through the use of the environment as a social science learning resource, students will be able to directly see, study, assess and analyze what and how something can happen and can find solutions to each problem and how to make appropriate decisions on these problems [18].

Through the use of the environment as a source of social science, the learning will be closer to real context. They will be able to directly see, study and assess and analyze what and how something can happen and can find solutions to each problem (problem solving) and how to make the right decisions on these problems (decision making)

\section{CONCLUSIONS}

The Covid-19 pandemic presents challenges and opportunities for the government and society. It cannot be predicted when this pandemic will end. Therefore, a simple way to deal with this pandemic is to prepare short-term and long-term strategies. The short-term strategy that has been carried out by the government is to provide direct cash assistance or capital loan assistance while a possible long-term strategy is to provide training to MSME owners. Then, it can be focused on the introduction and use of digital technology for MSMEs.

MSMEs in Garut has been able to demonstrate their ability to survive in difficult situations through various innovations. The challenges in facing the economic crisis in the Covid-19 pandemic become the issues that should be solved between the Government and the society. The government is expected to continue to provide various opportunities for the advancement of MSMEs, and the society is expected to be able to help MSMEs by using and buying domestic products.

The endurance of MSMEs in Garut can be used as part of social science resources. The ability to survive in the midst of the economic crisis can provide useful learning information for students. Through the use of the environment as a learning resource, students are expected to be able to explore meaningful knowledge.

\section{REFERENCES}

[1] T. P. Velavan, , \& C. G. Meyer, “ The covid-19 epidemic," Tropical medicine \& international health, 25(3), 278, 2020.

[2] March 26, 2020, Ministry of cooperativesand smes [Online]. Available : https://www.kompas.com/

[3] 2020. World Health Organization, "Coronavirus disease (COVID-19): situation report", 182, [Online]. Available : https://www.who.int

[4] March 11, 2020, Global panic which then has an impact on various aspects in humanity [Online]. Available : https://www.cnbcindonesia.com/news

[5] Mei, 2020, Ministry Healthy of Indonesia, [Online] . Available https://www.who.int/emergencies/diseases/novelcoronavirus-2019/

[6] A. Aufar, Faktor-faktor yang mempengaruhi penggunaan informasi akuntansi pada umkm ( survei pada perusahaan rekanan pt.pln (persero). Bandung, 2014. 
[7] Y. R. Suci, “ Perkembangan umkm (usaha mikro kecil dan menengah) di indonesia. Cano Ekonomos, 6(1), 51-58, 2012.

[8] Tetep, et.al, "The role of socio-economic background, family economic education and financial literacy on student decision making," Proceedings of the 4th Global Conference on Business Management \& Entrepreneurship (GCBME 4), 8 August 2019, Bandung, Indonesia. ISBN 9780367674717 Published December 8, 2020 by CRC Press 770 Pages 550 B/W Illustrations.

https://www.routledge.com/Advances-in-BusinessManagement-and-Entrepreneurship-Proceedingsof-the/Hurriyati-Tjahjono-Abdullah-SulastriLisnawati/p/book/9780367674717, 2020.

[9] R. Abdullah, "Pembelajaran berbasis pemanfaatan sumber belajar," J. Ilmiah Didaktika: Media Ilmiah Pendidikan dan Pengajaran, 12(2),2012.

[10]M. Abdul, Perencanaan pembelajaran, mengembangkan standar kompetensi guru Bandung: PT. Remaja Rosda Karya, 2008.

[11] M. Nachrawie, “ Sumber belajar lingkungan dalam pembelajaran ips di smpn 1 kusan hulu kabupaten tanah bumbu," J. Socius, 6(02), 2017.

[12] W. Sanjaya, Strategi pembelajaran berorientasi standar proses pendidikan. Jakarta: Prenada Media Grup, 2010.

[13]F. Nur, "Pemanfaatan sumber belajar dalam pembelajaran sains kelas $\mathrm{v}$ sd pada pokok bahasan makhluk hidup dan proses kehidupan. ISSN 1412565X J. Penelitian Pendidikan Vol. 13 No. 1, April 2012 hal 67-76, 2012.

[14] Wurdjinem, "Pengembangan sumber belajar ips melalui pemanfataan lingkungan dalam meningkatkan keterampilan proses di sekolah dasar," Carkrawala Pendidikan: J. Ilmiah Pendidikan ISSN 2442-8620 Vol 3 hal 453-470, 2006.

[15] J. Jumriani, "Kegiatan produksi dan distribusi di kampung sasirangan sebagai sumber belajar ips. J. Socius, 7(1), 2018.

[16] J.W.Creswell, "Qualitative inquiry and research design: choosing among five tradition," Qualitative Health Research, 1998.

[17] A. Amri, "Dampak covid-19 terhadap umkm di indonesia," BRAND J. Ilmiah Manajemen Pemasaran, 2(1), 123-131, 2020.

[18]Y. I. Santoso "Menghitung dampak covid-19 terhadap dunia usaha hingga umkm : https://nasional.kontan.co.id/news/menghitungdampak-covid-19-terhadap-dunia-usaha-hinggaumkm/page $=$ all, 2020.

[19]E. Hendarwati, "Pengaruh pemanfaatan lingkungan sebagai sumber belajar melalui metode inkuiri terhadap hasil belajar siswa sdn i sribit delanggu pada pelajaran ips," PEDAGOGIA: J. Pendidikan, 2(1), 59-70, 2013.. 